\title{
Bullying Types for Lombok Island Middle School Students and Solutions to Reduce It
}

\author{
*Agus Ramdani, I Putu Aratayasa, Jamaluddin \\ Departement of Biology Education, University of Mataram, Jl. Majapahit No. 62 Mataram, \\ Indonesia \\ *Corresponding Author e-mail: aramdani07@unram.ac.id
}

Received: October 2021; Revised: December 2021; Published: December 2021

\begin{abstract}
At this time in the educational environment there have been many worrying behaviors and acts of violence. One of the most frequent acts of violence is bullying behavior. The prevalence of bullying behavior that has increased from year to year has caused damage or adverse impacts for both the perpetrator and the victim. This study aims to describe bullying among students and actions to minimize it on the island of Lombok, which consists of Mataram City, West Lombok Regency, Central Lomok, East Lombok and North Lombok. The subjects of this study were the principal, class teacher, class students, BK teachers, and parents of students. Data collection techniques used documentation studies, questionnaires, observation sheets, and interview techniques. The data analysis technique uses three activity lines, namely data reduction, data presentation and conclusion drawing and uses data validity tests using data triangulation tests. The results showed that some students had been involved in bullying behavior. Of the three forms of bullying behavior, the verbal form is the most common bullying behavior in schools. In this study it was also found that the three aspects of bullying behavior, namely, carried out intentionally with or without a specific purpose, there is an element to hurt the victim, there is an imbalance of power and/or strength between the perpetrator and the victim of bullying, and it occurs repeatedly which is fulfilled. Efforts to minimize bullying is by planting character education which must be implemented in the learning process.
\end{abstract}

Keywords: Analysis, Bullying, Lombok Island Middle School

How to Cite: Ramdani, A., Artayasa, I., \& Jamaluddin, J. (2021). Bullying Types for Lombok Island Middle School Students and Solutions to Reduce It. Prisma Sains : Jurnal Pengkajian Ilmu dan Pembelajaran Matematika dan IPA IKIP Mataram, 9(2), 389-395. doi:https://doi.org/10.33394/j-ps.v9i2.4404

https://doi.org/10.33394/j-ps.v9i2.4404

Copyright $\odot$ 2021, Ramdani et al This is an open-access article under the CC-BY License.

\section{INTRODUCTION}

Bullying is aggressive behavior carried out by a person or group against other people or groups that is carried out repeatedly by hurting physically or mentally (Prasetyo, 2011). Bullying that occurs in schools has 3 integrated characteristics, namely: 1) actions that are intentionally carried out by the perpetrator to harm the victim, 2) actions that are carried out are not balanced so that it causes a feeling of pressure on the victim, and 3) actions that are carried out repeatedly (Maryam and Fatmawati, 2003). 2018). Children as victims of bullying will experience psychological and physical disorders, are more often lonely, and have difficulty making friends, while children as bullies tend to have low scores (Dwipayanti \& Komang, 2014). The impact of bullying in childhood can last a lifetime, both for victims and perpetrators of bullying themselves, as well as on young adults who show long-term effects due to bullying (Bondu, et al., 2016). However, bullies are found to be healthier than victims of bullying (Sufriani and Sari, 2017).

PISA 2018 data shows that bullying occurs in all countries and economies participating in PISA. On average across OECD countries, $23 \%$ of students reported being bullied at least 
a few times a month; $8 \%$ of students were classified as frequently bullied. However, 2018 PISA data reveal large differences between countries in students' reported exposure to bullying. In Brunei Darussalam, the Dominican Republic, Indonesia, Morocco and the Philippines, more than $40 \%$ of students reported being bullied at least a few times a month. In contrast, in Korea, the Netherlands, Portugal and Chinese Taipei, less than $15 \%$ of students reported so. In Brunei Darussalam, Dominican Republic and the Philippines, more than 20\% of students are often bullied, while in Beijing, Shanghai, Jiangsu and Zhejiang (China) (hereinafter "BSJZ [China]"), Iceland, Japan, Netherlands and Chinese Taipei less than 5\% of students are often bullied (OECD, 2019).

Certain types of bullying in schools are more common than others. While the prevalence of bullying varies substantially, depending on the age of the student, the country and culture in which he or she lives, and the type of study pursued (Chester et al., 2015; Craig et al., 2009), verbal and relational bullying are the most common types of bullying in Indonesia. among middle school age students (Thomas et al., 2015; Waasdorp and Bradshaw, 2015). Like PISA 2015, PISA 2018 found that in many countries, verbal and relational bullying was most common. On average across OECD countries, 14\% of students report that others make fun of them at least a few times a month; $10 \%$ reported that they were the object of malicious rumors at school; and 9\% reported that they did something on purpose. More than $10 \%$ of students in 67 of the 75 countries/economics for which data are available report that their peers make fun of them at least a few times a month. The same proportion of students in 55 of 75 countries and economies reported that they were the object of malicious rumors; and in 40 of 75 countries and economies where their schoolmates are often left out.

PISA 2018 data shows that physical bullying is less prevalent than verbal and relational bullying. On average across OECD Countries, about 7\% of students report being hit or pushed by another student at least a few times a month. A similar proportion of students reported that other students took or destroyed their belongings and that they were threatened by others. However, these percentages make up for large differences across countries and economies. One possible explanation is that different cultural and social norms can influence the way students in different countries perceive different types of violence. For example, in Baku (Azerbaijan), the Dominican Republic, Indonesia, Jordan, Morocco, and the Philippines, more than $20 \%$ of students reported having their belongings taken or destroyed, while in Japan, Korea and the Netherlands, less than 3\% of students reported.

Cases of bullying that often occur in education in Indonesia are increasingly worrying, the Indonesian Child Protection Commission (KPAI) said that from 2011 to August 2014 there were 1,480 cases of bullying that occurred in schools (KPAI, 2014). While in Aceh the number of bullying cases was not specifically stated, but cases of violence against children from January to December 2014 there were 25 cases with details: violence against children in cases of Domestic Violence (KDRT) as many as 5 cases, physical violence against children (beatings) 2 cases, 7 cases of sexual violence against children, 5 cases of child exploitation, 2 cases of drug-related children, 2 cases of trafficking in girls, and 2 cases of children in school (Sufriani and Sari, 2017). According to Noboru, et al., (2021) 32\% of students are in some form by their peers at school on one or more days during a period of one month. Victims of bullying experience the most serious consequences and are at greater risk for health and behavioral problems. Bullying can be divided into three categories, namely physical bullying, verbal bullying, and mental or psychological bullying (Nusantara, 2008). This study aims to describe the act of bullying among junior high school students on the island of Lombok.

\section{METHOD}


This study uses a descriptive qualitative approach. According to (Arikunto, 2013) descriptive research is research that is intended to investigate the circumstances, conditions or other things that have been mentioned, the results of which are presented in the form of a research report. Research that produces descriptive data in the form of written or spoken words from people and observed behavior.

This research was carried out in several junior high schools on the island of Lombok, consisting of Mataram City, West Lombok Regency, Central Lomok, East Lombok and North Lombok. The subjects of this study were the principal, class teacher, class students, BK teachers, and parents of students. Data collection techniques used documentation studies, bullying questionnaires, observation sheets, and interview techniques. The questionnaire used in this research is a questionnaire compiled by the researchers themselves with reference to aspects of bullying behavior. The assessment on this questionnaire is adjusted to the Likert scale, namely a weight of 1 is given for the answer choice "never", 2 for the answer choice "rarely", 3 for the answer choice "often", and 4 for the answer choice "always". In addition to using a closed questionnaire, an open questionnaire was also used to help obtain additional results in getting an overview of bullying behavior in adolescents.

Data analysis used Miles \& Huberman model data analysis which consisted of data reduction, data presentation, and drawing conclusions. As for the validity of the data test with data triangulation techniques. The triangulation technique in this study uses data triangulation and source triangulation, carried out by checking the data. This analysis aims to describe bullying behavior in junior high school teenagers.

\section{RESULTS AND DISCUSSION}

Bullying is the negative behavior of a person or more towards the victim that is carried out repeatedly, occurs from time to time by hurting physically or mentally (Prasetyo, 2011). Bullying consists of actions such as making threats, spreading rumors, physically/verbally attacking, and alienating someone from the group. Bullying can occur through people or through technology (CDC, 2014).

Bullying is a common phenomenon and a universal problem in school-age children (Tsitka et al, 2014). The prevalence of bullying behavior in children in Canada is around 9\% $21 \%$. A study that examined the behavior of girls and boys aged 12-17 years in 5 countries: Cambodia, Indonesia, Nepal, Pakistan and Vietnam, found that $71 \%$ of children, both male and female, had experienced violence within 6 months. last in school ((ICRW, 2014).

Bullying can be divided into three categories, namely physical bullying, verbal bullying and mental or psychological bullying (Nusantara, 2008). Physical bullying occurs when someone is physically harmed through actions, verbal bullying is bullying that is done by threatening, making sexual calls, and spreading false or malicious rumors and mental or psychological bullying are actions that are carried out by ignoring other people, isolating and making other students do not like someone (Sufriani and Sari, 2017). The results of bullying that have been obtained in junior high schools on the island of Lombok, observations of junior high schools in West Lombok show that the forms of action that are often perceived are verbal bullying, physical and mental intimidation. The types of bullying that are most often done by students are verbal and physical. In a junior high school on the island of Lombok, verbal bullying is in the form of making fun of parents' names, making fun of physical form, demeaning parents' work, while the violence that occurs is physical such as hitting, slapping, kicking.

From bullying, it was found the impact of bullying behavior, the impact of bullying behavior will inhibit children's behavior in self-actualization because bullying behavior does not give a sense of security and comfort, makes victims feel intimidated, low self-esteem, worthless, difficult to concentrate in learning, and unable to socialize. with their environment 
(Amini, 2008; Damri et al. 2017). So that school is no longer a fun place for students, but instead becomes a scary and traumatizing place (Mudjijanti, 2012).

The high tendency of verbal bullying behavior compared to other forms of bullying is due to the fact that in general people tend to view verbal bullying as normal and have no serious consequences compared to physical or psychological bullying. In fact, the form of verbal bullying has the same negative impact as bullying in physical and psychological forms (Baldry, 2003). Whatever its form, bullying is a serious problem that both have psychological consequences and social consequences for both the victim and the perpetrator. Olweus and Limber (2010) stated that bullying has a lifelong effect. The majority of students who have been bullied admit that the most frequent targets of bullying are friends who are difficult to get along with and friends whose behavior or appearance is different. Physical bullying occurs when someone is physically harmed through actions, verbal bullying is bullying that is done by threatening, making sexual calls, and spreading false or malicious rumors, mental/psychological bullying is an act that is carried out by ignoring other people, isolating and making students others do not like someone (Meliana and Fadlil, 2019).

Efforts must be made to minimize the occurrence of cases of bullying among students is to implement character education into learning, with character education students can distinguish traits that should not be done by fellow students. According to Wijayanti and Uswatun (2019) the cultivation of character education since elementary school age has a very important role, especially in efforts to combat bullying caused by many factors such as the influence of children's television viewing. The many negative impacts of bullying make character education very necessary to form healthy character and morals in children (Hiliard, et al., 2014; Freeman, 2014).

The link between education, culture, and religion is very strong in this Indonesian curriculum document. studies show that this interaction effectively affects bullying prevention (Noboru, et al., 2021). Pancasila and Citizenship Education too as religious education, included in the school curriculum as a subject, while character education is integrated into throughout the learning process (Eka, 2017) This lesson covers bullying prevention. It shows ownership by both governments and schools, which were also identified as success factors implementation of school health. Pancasila and civic education covers topics such as principles and practice conflict resolution, tolerance of differences, respect individual rights, and participatory instruction (Berkowitz and Bier, 2017) Current studies emphasize the importance of character education.34 Character education is in the spotlight of the Indonesian government Long Term Development Plan 2005-2025 (Cinantya, et al., 2018). The study findings show that the improvement of students' character prevent bullying in schools. Previous research also concluded that character education is effective in preventing bullying (Berkowitsz, et al., 2007)

Character education in children is a very important foundation in building personality both during development and for the future (Izzati, et al., 2019). One of the educational factors that play a very important role is the educator, who will teach and be an example for his students. Things that should not be eroded by the times are the cultivation of good character in educating students, including what must be prevented is acts of violence against students, maybe it can happen in the world of education, both by educators and fellow students (Arsyah, et al. al., 2019).

The Ministry of Education and Culture has implemented a program to strengthen character education at all levels of formal education in Indonesia (Hubbi, et al., 2020). Character education at the institutional level aims to form a school culture that is practiced by all school members (Lin, 2015). School is one of the strategic places in character building, apart from family and society. This is what underlies the need for character education programs in schools. 
Planting character education for each school with various activities that can support the cultivation of good character (Hamid, 2017). It is hoped that through character education, students can independently improve and use their knowledge, to learn and internalize and personalize character values and noble moral values so that they manifest in everyday behavior.

Character education as all efforts made by educators, to influence students. Educators as facilitators of character formation of students and efforts to facilitate this can be in the form of: exemplary behavior of educators, how educators speak and deliver material, how educators are tolerant and so on. This development will result in changes to life, especially will be able to affect the characters that have been instilled since birth, of course, good characters that have been attached to each of them. Related to what was conveyed by (Rohman, 2014) that the majority of people have a desire to move forward and develop for the better. One way that is taken is through educational activities in order to achieve progress.

\section{CONCLUSION}

Some students have been involved in bullying behavior. Of the three forms of bullying behavior, the verbal form is the most frequent bullying behavior. In this study it was also found that the three aspects of bullying behavior, namely, carried out intentionally with or without a specific purpose, there is an element to hurt the victim, there is an imbalance of power and/or strength between the perpetrator and the victim of bullying, and it occurs repeatedly which is fulfilled. Efforts to minimize bullying is by planting character education which must be implemented in the learning process.

\section{RECOMMENDATION}

Character education must be implemented in learning, it is intended that students have good character, students understand which behaviors should not be carried out by fellow students. Character education aims to minimize bullying.

\section{REFERENCES}

Arsyah, U. I., Arsyah, R. H., Pratiwi, M., \& Lestari, N. (2019). Strengthening Character Education With The Implementation Of Machine Learning In The Millennial Era Industrial Revolution 4.0. In Journal of Physics: Conference Series (Vol. 1339, No. 1, p. 012036). IOP Publishing.

Baldry, A. C. (2003). Bullying in schools and exposure to domestic violence. Child abuse \& neglect, 27(7), 713-732.

Berkowitz, M. W., \& Bier, M. C. (2005). What works in character education: A researchdriven guide for educators. Washington, DC: Character Education Partnership.

Berkowitz, M. W., Bier, M. C., \& McCauley, B. (2017). Toward a science of character education. Journal of Character Education, 13(1), 33-51.

Berkowitz, M. W., Bier, M. C., \& McCauley, B. (2017). Toward a science of character education. Journal of Character Education, 13(1), 33-51.

Bondü, R., Rothmund, T., \& Gollwitzer, M. (2016). Mutual long-term effects of school bullying, victimization, and justice sensitivity in adolescents. Journal of adolescence, 48, 62-72.

Chester, K. L., Callaghan, M., Cosma, A., Donnelly, P., Craig, W., Walsh, S., \& Molcho, M. (2015). Cross-national time trends in bullying victimization in 33 countries among children aged 11, 13 and 15 from 2002 to 2010. The European Journal of Public Health, 25(suppl_2), 61-64. 
Cinantya, C., Suriansyah, A., \& Asniwati, A. (2018). the Model of Religion-Based Character Education (Multi-Site Integrated Islamic Paud Sabilal Muhtadain and Paud Islam Mawaddah Banjarmasin, Indonesia). European journal of education studies.

Craig, A. D. (2009). Emotional moments across time: a possible neural basis for time perception in the anterior insula. Philosophical Transactions of the Royal Society B: Biological Sciences, 364(1525), 1933-1942.

Dwipayanti, I. A., \& Indrawati, K. R. (2014). Hubungan antara tindakan bullying dengan prestasi belajar anak korban bullying pada tingkat sekolah dasar. Jurnal Psikologi Udayana, 1(2), 251-260.

Eka, E. (2017). Revisiting Character Education from Islamic Perspective: A Quest for Character-based Education in Indonesia. Ulumuna, 21(1), 1-33.

Freeman, G. G. (2014). The implementation of character education and children's literature to teach bullying characteristics and prevention strategies to preschool children: An action research project. Early Childhood Education Journal, 42(5), 305-316.

Hamid, A. (2017). Pendidikan Karakter Berbasis Pesantren: Pelajar dan Santri dalam era IT dan Cyber Culture. Imtiyaz.

Hilliard, L. J., Bowers, E. P., Greenman, K. N., Hershberg, R. M., Geldhof, G. J., Glickman, S. A., ... \& Lerner, R. M. (2014). Beyond the deficit model: Bullying and trajectories of character virtues in adolescence. Journal of Youth and Adolescence, 43(6), 9911003.

Hubbi, U., Ramdani, A., \& Setiadi, D. (2020). Integrasi Pendidikan Karakter kedalam Pembelajaran Pendidikan Agama Islam dan Pendidikan Kewarganegaraan di Era Milenial. JISIP (Jurnal Ilmu Sosial dan Pendidikan), 4(3).

Izzati, U. A., Bachri, B. S., Sahid, M., \& Indriani, D. E. (2019). Character Education: Gender Differences In Moral Knowing, Moral Feeling, And Moral Action In Elementary Schools In Indonesia. Journal for the Education of Gifted Young Scientists, 7(3), 547-556.

Lin, A. (2015). Citizenship Education In American Schools And Its Role In Developing Civic Engagement: A Review Of The Research. Educational Review, 67(1), 35-63.

Maryam, S., \& Fatmawati, F. (2018). Kematangan emosi remaja pelaku bullying. Jurnal Kajian Bimbingan dan Konseling, 3(2), 69-74.

Meliana, N., \& Fadlil, A. (2019, November). Identification of Cyber Bullying by using Clustering Methods on Social Media Twitter. In Journal of Physics: Conference Series (Vol. 1373, No. 1, p. 012040). IOP Publishing.

Noboru, T., Amalia, E., Hernandez, P. M. R., Nurbaiti, L., Affarah, W. S., Nonaka, D., ... \& Kobayashi, J. (2021). School-based education to prevent bullying in high schools in Indonesia. Pediatrics international, 63(4), 459-468.

Nusantara, A. (2008). Bullying: Mengatasi kekerasan di sekolah dan lingkungan. Jakarta: Grasindo.

OECD. (2019). PISA 2018 assessment and analytical framework. OECD publishing.

Olweus, D., \& Limber, S. P. (2010). Bullying in school: evaluation and dissemination of the Olweus Bullying Prevention Program. American journal of Orthopsychiatry, 80(1), 124.

PISA. (2015). Draft Science Framework PISA 2015

Prasetyo, A. B. E. (2011). Bullying di sekolah dan dampaknya bagi masa depan anak. El Tarbawi, 4(1), 19-26.

Rohman, A. (2014). Karakter Kelompok Aliran Islam dalam Merespons Islamic Social Networking di Kabupaten Banyumas. Jurnal Pendidikan Karakter, (2).

Sufriani, S., \& Sari, E. P. (2017). Faktor yang mempengaruhi bullying pada anak usia sekolah di sekolah dasar Kecamatan Syiah Kuala Banda Aceh. Idea Nursing Journal, 8(3). 
Thomas, H. J., Connor, J. P., \& Scott, J. G. (2015). Integrating traditional bullying and cyberbullying: challenges of definition and measurement in adolescents-a review. Educational psychology review, 27(1), 135-152.

Tumon, M. B. A. (2014). Studi deskriptif perilaku bullying pada remaja. CALYPTRA, 3(1), 117.

Waasdorp, T. E., \& Bradshaw, C. P. (2015). The overlap between cyberbullying and traditional bullying. Journal of adolescent health, 56(5), 483-488.

Wijayanti, C. P., \& Uswatun, A. T. (2019, July). Perangi Tindak Perundungan (Bullying) dengan Penanaman Pendidikan Karakter Sejak Dini Pada Peserta Didik Sekolah Dasar. In PROSIDING SEMINAR NASIONAL PAGELARAN PENDIDIKAN DASAR NASIONAL (PPDN) 2019 (Vol. 1, No. 1, pp. 16-26). 